\title{
Population and function analysis of cultivable bacteria associated with spores of arbuscular mycorrhizal fungus Gigaspora margarita
}

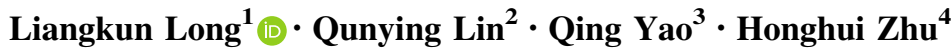

Received: 17 October 2016/Accepted: 8 January 2017/Published online: 8 April 2017

(C) The Author(s) 2017. This article is an open access publication

\begin{abstract}
This study was aimed to investigate the diversity and function of bacterial population associated with $\mathrm{Gi}$ gaspora margarita spores. The fungus was propagated in sterilized sand/soil pots using alfalfa (Medicago sativa), grain sorghum (Sorghum bicolor), or maize (Zea mays) as host plants, or in sterilized vermiculite pots using alfalfa as host plants, respectively. Bacteria were isolated from the new-formed spores using diluted plate method, and typical bacterial isolates were identified according to 16S rRNA gene phylogenetic analysis. Total 43 bacterial isolates affiliated to three phyla and 23 genera were obtained. The spore-associated bacterial communities were obviously different among the four source spores, suggesting that plant species or substrates could influence the bacterial
\end{abstract}

L. Long and Q. Lin contribute equally to the work.

Electronic supplementary material The online version of this article (doi:10.1007/s13205-017-0612-1) contains supplementary material, which is available to authorized users.

Liangkun Long

longlk602@njfu.edu.cn

$\square$ Honghui Zhu

zhuhh@gdim.cn

1 College of Chemical Engineering, Nanjing Forestry University, Nanjing 210037, China

2 Nanjing Institute for the Comprehensive Utilization of Wild Plants, Nanjing 210042, China

3 College of Horticulture, South China Agricultural University, Guangzhou 510642, China

4 Guangdong Institute of Microbiology, Guangdong Provincial Key Laboratory of Microbial Culture Collection and Application, Guangdong Open Laboratory of Applied Microbiology, State Key Laboratory of Applied Microbiology South China, Guangzhou 510070, China population. Bacillus and Streptomyces were most frequently associated with the fungal spores. Function analysis of these bacteria by plate tests, it was found that about $30.2 \%$ isolates stimulated the spore germination, five out of seven tested isolates improved the hyphal growth, total $57.5 \%$ of the tested isolates solubilized phosphorus at different levels, $15 \%$ isolates degraded chitin, and a few isolates suppressed the growth of Escherichia coli or Staphylococcus aureus. In pot experiment, three bacterial isolates (belonging to Curtobacterium, Ensifer, or Bacillus, respectively) displayed improvement effect on alfalfa growth and/or the colonization of roots by G. margarita.

Keywords Fungal spores - Cultivable bacteria .

Stimulation of spore germination · Plant growth promotion

\section{Introduction}

Arbuscular mycorrhizal fungi (AMF) are important symbiotic partner of most terrestrial plant species. Soil bacteria selectively associated with AMF could possibly serve as the third partner of the mycorrhizal symbiosis (Levy et al. 2009; Lecomte et al. 2011; Bidondo et al. 2016). Several of these bacteria displayed beneficial effects on the performance of AMF, including the promotion of fungal spore germination, hyphal growth, the colonization of roots, and the protein expression and lipid profile (Garbaye 1994; Hildebrandt et al. 2002; Salvioli et al. 2010). Information about AMF-associated bacterial communities and their possible functions is necessary for understanding the ecological roles of the bacteria and revealing mycorrhizal ecosystem. The spore-associated bacteria (SAB) of $\mathrm{Gi}$ gaspora margarita MAFF 520054 were analyzed with PCR-DGGE method, and indicated that host plants or 
substrates could influence the bacterial composition (Long et al. 2008). In this study, the bacterial populations associated with the fungal spores were investigated by cultured method and potential functions of these bacteria were analyzed.

\section{Materials and methods}

\section{Biomaterials}

Gigaspora margarita MAFF 520054 (from the Ministry of Agriculture, Forestry, and Fisheries Gene bank, Tsukuba, Japan) was maintained as pure propagation in our laboratory by subculturing in sand/soil pots using white cover (Trifolium repens) as host plant. In this study, G. margarita MAFF 520054 was propagated by four "plant-substrate" systems, respectively, namely, sterilized sand/soil mixture $(1: 1, \mathrm{v} / \mathrm{v})$ pots combined with alfalfa (Medicago sativa), grain sorghum (Sorghum bicolor) or maize (Zea mays), and sterilized vermiculite combined with alfalfa. The pot experiments were carried out in a greenhouse. One-liter plastic pots were filled with the substrates, and the substrate moisture was kept at about $60 \%(\mathrm{v} / \mathrm{v})$ during plant growth. In each pot, about $10 \mathrm{~g}$ of AMF inoculum and ten (for alfalfa) or two (for grain sorghum or maize) plant seeds were used, and 0.11 modified Hoaglands solution (macroelements were adjusted to $1 / 10$ strength) was watered every 2 weeks. After approximately 4 months, the substrates mixed with AMF propagations and host roots were air dried, and the fungal spores were collected from the mixture immediately by wet sieving as previously reported (Long et al. 2008). Spores were stored under $4{ }^{\circ} \mathrm{C}$ and subsequently conducted to the isolation of spore-associated bacteria $(\mathrm{SAB})$ as soon as possible.

\section{Isolation and identification of SAB}

For each "plant-substrate" treatment, fitly mature and healthy G. margarita spores were used to isolate SAB. The fungal spores were put into a 1.5-ml Eppendorf tube, and washed three times with sterilized $0.75 \% \mathrm{NaCl}$ solution. Then, the spores were suspended in $100 \mu \mathrm{l}$ of $0.75 \% \mathrm{NaCl}$ solution and crushed with a sterilized mini-pestle. Three aliquots of tenfold or $10^{2}$-fold dilutions of each fraction suspension were spread on Tryptic-Soy agar (TSA) medium. The bacterial CFU (colony formed unit) per plate was counted, and bacterial colonies representing different morphology were numbered and picked out after incubated at $26{ }^{\circ} \mathrm{C}$ for 4 days. To identify the bacteria, genomic DNA of each isolate was prepared by boiled method (Araújo et al. 2004) or lysozyme-SDS method (Rivera et al. 2003). Then, the 16S rRNA genes were PCR amplified with primer $27 \mathrm{f}\left(5^{\prime}\right.$-agagtttgatcctggctcag- $\left.3^{\prime}\right)$ or $338 \mathrm{f}\left(5^{\prime}\right.$-actcctacgggaggcagcag- $\left.3^{\prime}\right)$ paired with primer $1541 \mathrm{r}$ ( $5^{\prime}$-aaggaggtgatccagccgca- $3^{\prime}$ ) (Brosius et al. 1981; Cocolin et al. 2001), respectively. The amplified DNA fragments were sequenced by Invitrogen Biotechnologies Co. Ltd (Shanghai, China), and the target sequences were analyzed using BLAST on the NCBI web (http://www.ncbi.nim.nih.gov/). The related sequences were collected and aligned using the ClustalX 1.83 software, and phylogenetic trees were constructed using the neighbor-joining method (Kimura's correction model) with the Mega 4 software. The topology of the distance tree was tested by resampling data with 1000 bootstraps to provide confidence estimates.

\section{Effect of SAB on fungal spore germination and hyphal growth}

To investigate the effect of bacterial isolates on germination of the fungal spore, each isolate was suspended with sterilized $\mathrm{dd}_{2} \mathrm{O}$ up to $10^{8}$ cells per milliliter after cultured on TSA tube slant at $26{ }^{\circ} \mathrm{C}$ for $48 \mathrm{~h}$. Surface-decontaminated G. margarita spores were prepared with reported method (Karandashov et al. 2000). The 'clean' spores $(n=15-25)$ were immerged into the bacterial suspension for $10 \mathrm{~min}$ at room temperature and transferred to a $1 \%$ water agar (WA) plate with a soft tweezer, then incubated at $26{ }^{\circ} \mathrm{C}$ for 14 days. Spore germination was detected under a dissection microscope, and it was recorded as germination when the tube length exceeded the spore diameter.

To assess the effect of SAB on hyphal growth of the fungus, seven isolates were selected and the same co-incubation of SAB with the fungal spores was conducted as described above. Per 15 'clean' spores were used as a group, and treatment contained no bacterial cells was conducted as control. Four replications were established for each treatment. After incubation for 15 days at $26^{\circ} \mathrm{C}$, hyphal elongation (accurate to $\mathrm{mm}$ ) of the germinated spores was assessed by the $2 \mathrm{~mm}$ grid method (Bécard et al. 1992).

\section{Phosphate solubilization, chitin degradation, and antimicrobial effects of SAB}

GL medium (glucose $10 \mathrm{~g}$, yeast extraction $2 \mathrm{~g}, 10 \%$ $\mathrm{CaCl}_{2}$ solution $10 \mathrm{ml}, 10 \% \mathrm{~K}_{2} \mathrm{HPO}_{4}$ solution $10 \mathrm{ml}$, $\mathrm{ddH}_{2} \mathrm{O} 1000 \mathrm{ml}, \mathrm{pH}$ 7.0) plates contained $\mathrm{CaHPO}_{4}$ were prepared according to the document method (Cruz et al. 2008). Per five SAB isolates as a group were inoculated onto a GL plate with an inoculation loop, and cultured at $26{ }^{\circ} \mathrm{C}$ for $3-4$ days. Transparent zone produced around the colony was measured with a ruler, and the corresponding isolate was recorded as a $\mathrm{P}$-solubilizing bacterium. The 
same method was used to assess chitin-decomposing activity of $\mathrm{SAB}$ replacing GL medium by chitin medium (colloidal chitin $15 \mathrm{~g}$, yeast extraction $3 \mathrm{~g},\left(\mathrm{NH}_{4}\right)_{2} \mathrm{SO}_{4} 1 \mathrm{~g}$, $\mathrm{K}_{2} \mathrm{HPO}_{4} 1.36 \mathrm{~g}, \mathrm{MgSO}_{4} \cdot 5 \mathrm{H}_{2} \mathrm{O} 0.3 \mathrm{~g}$, ddH $\mathrm{d}_{2} \mathrm{O} 1000 \mathrm{ml}, \mathrm{pH}$ 7.0). At the same time, Escherichia coli, Staphylococcus aureus, and Fusarium oxysporum were used to assess antimicrobial effects of the bacterial isolates with the reported methods (El-Sayed et al. 2014).

\section{Effect of SAB on fungal colonization and plant growth}

Autoclaved sand/soil mixture at ratio of 1:1 (v/v) was used as substrates (organic matter $0.42 \%, \mathrm{~N} 65.2 \mathrm{mg} / \mathrm{kg}$, P $27.3 \mathrm{mg} / \mathrm{kg}, \mathrm{K} 15.7 \mathrm{mg} / \mathrm{kg}$, Ca $101.0 \mathrm{mg} / \mathrm{kg}$, pH 6.9) in pot experiment. For each isolate, the bacterial suspension (about $5.0 \times 10^{8}$ cells per milliliter) was prepared as described above. Healthy and surface decontaminated $G$. margarita spores were immerged into the bacterial suspension for $10 \mathrm{~min}$ at room temperature. In a pot $(8 \mathrm{~cm} \times 10 \mathrm{~cm})$ containing $320 \mathrm{~g}$ substrates, two alfalfa seeds were planted and inoculated with five treated fungal spores and $5 \mathrm{ml}$ of the corresponding bacterial suspension. Five replications were carried out for each treatment. Plant management was conducted as described above. After 4-month growth, plants were harvested and roots were washed and isolated from the substrates. Fresh and dry weights of plant shoots were recorded immediately on harvesting and after drying at $70{ }^{\circ} \mathrm{C}$ for $24 \mathrm{~h}$. Random samples of fresh roots at $0.5 \mathrm{~g}$ from every treatment were stained with trypan blue and examined under a microscope. Rate of AMF colonization in roots was measured by the reported method (Mcgonigle et al. 1990).

\section{Statistical analysis}

For data analysis, one-way ANOVA was performed with the SPSS v17.0 software using Duncan's Multiple Range Test (DMRT). A $P$ value of less than 0.05 was considered statistically significant.

\section{Results and discussion}

\section{Cultivable bacteria associated with $G$. margarita spores}

Fungal spores were collected from the four "plant-substrate" systems, namely, from alfalfa in sand/soil pots (AS), alfalfa in vermiculite pots (AV), grain sorghum in sand/soil pots (GS), and maize in sand/soil pots (MS), respectively. Average numbers at 60, 172, 65, and 53 bacterial CFU per spore were isolated from the new- formed spores in AS, AV, GS, and MS groups, respectively (Supplementary Figure S1). More than two times of cultivable bacteria isolated from the spores in $\mathrm{AV}$ group compared to AS group, suggesting that vermiculite with better air permeability than sand/soil was beneficial to the breeding of bacteria. According to morphology differentia, total 43 bacterial isolates were selected and purified in the isolation experiments using four different spores (Table 1).

By the phylogenetic analysis of the 16S rRNA genes (accession numbers: EU072704 to EU072717 and EU589400 to EU589429) of these isolates, they were affiliated to 3 phyla and 23 genera (Supplementary Figures $\mathrm{S} 2 \mathrm{a}-\mathrm{S} 2 \mathrm{c})$. Total 18 isolates were affiliated to 12 genera in the phylum of Proteobacteria, 15 isolates were affiliated to 8 genera in the phylum of actinobacteria, and the rest of 10 bacterial isolates were contained in 3 genera of Firmicutes (Table 1). The bacteria belonging to these phyla were also found on the spores of other AMF species, including Funneliformis caledonium, Racocetra alborosea,

Table 1 Taxonomic positions and the diversity of the spore-associated bacteria of $G$. margarita

\begin{tabular}{|c|c|c|c|c|c|c|}
\hline \multirow[t]{2}{*}{ Phylum } & \multirow[t]{2}{*}{ Genus } & \multirow[t]{2}{*}{ Total } & \multicolumn{4}{|c|}{$\begin{array}{l}\text { Source } \\
\text { environment of the spores }\end{array}$} \\
\hline & & & AS & $\mathrm{AV}$ & GS & MS \\
\hline \multirow{12}{*}{$\begin{array}{l}\text { Proteobacteria } \\
\quad(12 \text { genera })\end{array}$} & Achromobacter & 1 & 0 & 0 & 1 & 0 \\
\hline & Aquitalea & 5 & 0 & 5 & 0 & 0 \\
\hline & Bosea & 1 & 0 & 0 & 1 & 0 \\
\hline & Burkholderia & 1 & 0 & 0 & 1 & 0 \\
\hline & Cupriavidus & 3 & 0 & 0 & 0 & 3 \\
\hline & Ensifer & 1 & 1 & 0 & 0 & 0 \\
\hline & Lysobacter & 1 & 0 & 0 & 1 & 0 \\
\hline & Mitsuaria & 1 & 1 & 0 & 0 & 0 \\
\hline & Proteus & 1 & 0 & 0 & 1 & 0 \\
\hline & Pseudomonas & 1 & 1 & 0 & 0 & 0 \\
\hline & Ralstonia & 1 & 0 & 1 & 0 & 0 \\
\hline & Rhizobium & 1 & 0 & 0 & 0 & 1 \\
\hline \multirow{8}{*}{$\begin{array}{l}\text { Actinobacteria } \\
\text { (8 genera) }\end{array}$} & Amycolatopsis & 1 & 0 & 0 & 0 & 1 \\
\hline & Arthrobacter & 2 & 0 & 2 & 0 & 0 \\
\hline & Curtobacterium & 1 & 0 & 1 & 0 & 0 \\
\hline & Gordonia & 1 & 0 & 1 & 0 & 0 \\
\hline & Leifsonia & 3 & 3 & 0 & 0 & 0 \\
\hline & Mycobacterium & 1 & 0 & 1 & 0 & 0 \\
\hline & Nocardia & 2 & 0 & 0 & 1 & 1 \\
\hline & Streptomyces & 4 & 2 & 0 & 1 & 1 \\
\hline \multirow{3}{*}{$\begin{array}{l}\text { Firmicutes } \\
\quad(3 \text { genera) }\end{array}$} & Bacillus & 5 & 2 & 0 & 1 & 2 \\
\hline & Brevibacillus & 1 & 0 & 0 & 0 & 1 \\
\hline & Paenibacillus & 4 & 0 & 0 & 2 & 2 \\
\hline
\end{tabular}

$A S$ alfalfa in sand/soil pot, $A V$ alfalfa in vermiculite pot. $G S$ grain sorghum in sand/soil pot, $M S$ maize in sand/soil pot 

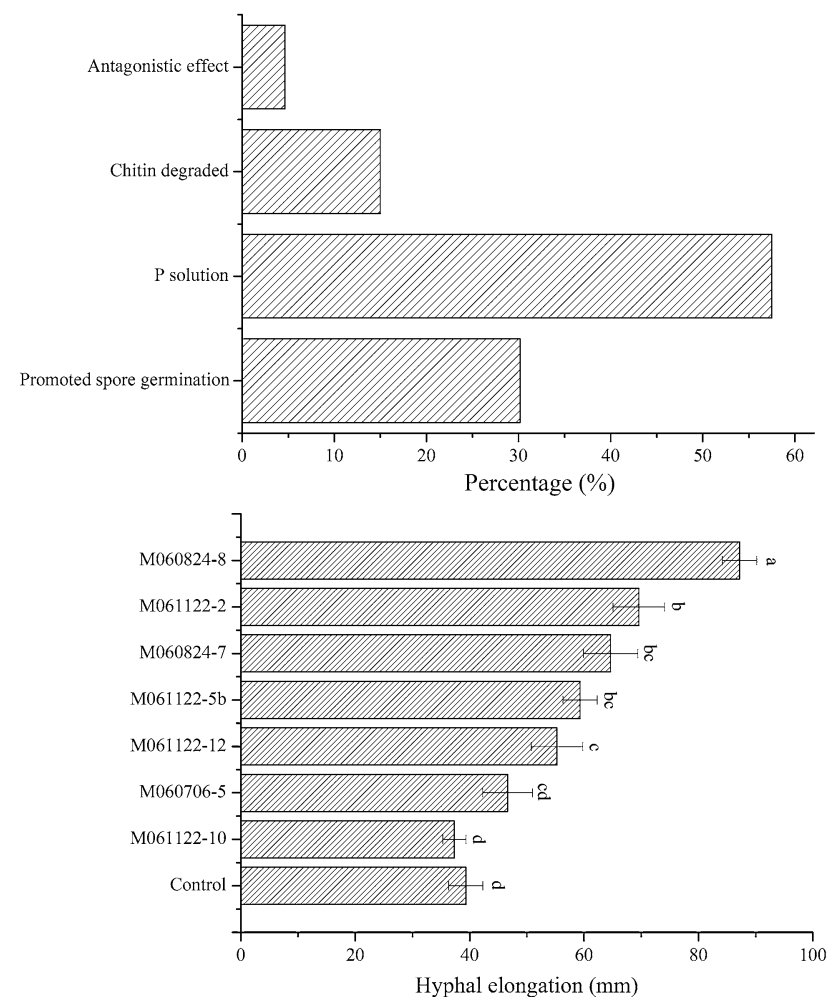

Fig. 1 Functional evaluation of bacteria associated with the spores of G. margarita. a Percentages of bacterial isolates displaying different functions in plate tests. Total 43 isolates were tested, and the detailed records were listed in Supplementary Table S5. b Effect of sporeassociated bacteria on in vitro hyphal growth of $G$. margarita after 15 days culture. Strains M060706-5, M060824-7, M060824-8, M061122-2, M061122-5b, M061122-10, and M061122-12 were mostly related to Ensifer adhaerens, Curtobacterium luteum, Mycobacterium mucogenicum, Paenibacillus glycanilyticus, Cupriavidus pauculus, Bacillus bataviensis, and Brevibacillus agri, respectively. Each data is the average of four replications. Different letters above the error bars indicate significant differences by DMRT test at $P<0.05$

and Funneliformis mosseae (Selvakumar et al. 2016). It was showed that most isolates from the fungal spores propagated under different host plant or substrate environments were affiliated to different genera. No common genus was isolated from the groups of $\mathrm{AS}$ and $\mathrm{AV}$, which contained the same alfalfa plants in sand/soil or vermiculite, respectively (Table 1; Supplementary Figures S2aS2c). It was indicated that different chemical or physical conditions of the two substrates led to proliferation of distinctly different bacterial populations. The most isolates in AS group were different with those in GS or MS group which only differentiated in plant species. Obviously, host plant species also influenced the bacterial population structures. The results were consistent with the previous studies based on the molecular communication analysis of the SAB of G. margarita and Gigaspora rosea (Long et al. 2008). Four of ten isolates belonging to Streptomyces or
Bacillus in AS group were simultaneously found in GS and MS groups which used different host plants in the same sand/soil pots. In addition, the common genera between GS and MS groups were Nocardia, Streptomyces, Bacillus, and Paenibacillus (Table 1). These data indicated that some bacterial genera developed specific interactions with AMF, as previously reported (Scheublin et al. 2010; Lecomte et al. 2011).

\section{Function analysis of SAB in plate tests}

According to the results of plate tests, about $30.2 \%$ isolates promoted (Fig. 1a) and $11.6 \%$ isolates inhibited the spore germination, while $58.1 \%$ isolates had no significant effect on the germination (Supplementary Tables S1-S5). It was found that $57.5 \%$ tested isolates (three could not grow on the test plate) solubilized phosphorus at different levels (Fig. 1a; Supplementary Table S5). P-solubilizing bacteria were easily isolated from AMF (Taktek et al. 2015), suggesting their roles in improvement of $\mathrm{P}$ uptake by AMF or root hair. Previous studies revealed that some AMF-associated bacterial isolates could degrade chitin, which is one of main components of AMF spore walls, and thereby improved fungal spore germination (Ames et al. 1989; Selvakumar et al. 2016). In our study, six chitin-decomposing bacteria were isolated, and they belong to Mitsuaria (M060706-1b), Streptomyces (M060706-9), Curtobacterium (M060824-7), Paenibacillus (M061017-6), Paenibacillus (M061122-6), and Streptomyces (M061122-7), respectively (Fig. 1a; Supplementary Table S5). These data provided an additional proof for the speculation. In addition, only $4.65 \%$ isolates suppressed the growth of $E$. coli or $S$. aureus, and no one could suppress $F$. oxysporum in our test (Fig. 1a; Supplementary Table S5). It was speculated that antimicrobial activity was not the main function of the SAB from G. margarita MAFF 520054.

The bacteria associated with AMF or the endophytic bacteria of plant could improve the spore germination and hyphal growth of Glomus clarum and/or Glomus intraradices (Xavier and Germida 2003; Sundram et al. 2011). In this research, total seven isolates belonging to different genera and displaying improvement effect (except M061122-12) on spore germination were picked out to assess the effect on hyphal growth. It was found that the seven tested isolates except M060706-5 and M061122-10 showed positive effect on the hyphal elongation, including the isolate M061122-12 which could not promote the fungal spore germination (Fig. 1b; Supplementary Table S5). The hyphal length treated with isolate M060824-8 (the mostly related to Mycobacterium mисоgenicum) was 2.2 times of the control group. The results indicated that stimulation of fungal growth was an important function of bacteria associated with AMF. 
Table 2 Effect of spore-associated bacterial isolates on the growth of alfalfa and colonization by G. margarita

\begin{tabular}{lllll}
\hline Bacterial isolates & $\begin{array}{l}\text { Fresh weight } \\
\text { of stem/leaf }(\mathrm{g} / \mathrm{pot})\end{array}$ & $\begin{array}{l}\text { Dry weight } \\
\text { of stem/leaf }(\mathrm{g} / \mathrm{pot})\end{array}$ & $\begin{array}{l}\text { Fresh weight } \\
\text { of roots }(\mathrm{g} / \text { pot })\end{array}$ \\
\hline M060706-5 & $1.40 \mathrm{a}$ & $0.32 \mathrm{ab}$ & $0.68 \mathrm{a}$ & $\begin{array}{c}\text { Colonization }(\%) \\
\text { M060824-7 }\end{array}$ \\
M060824-8 & $1.51 \mathrm{a}$ & $0.34 \mathrm{a}$ & $0.49 \mathrm{ab}$ & $29.9 \mathrm{ab}$ \\
M061122-2 & $1.27 \mathrm{ab}$ & $0.30 \mathrm{ab}$ & $0.42 \mathrm{~b}$ & $31.2 \mathrm{ab}$ \\
M061122-5b & $1.24 \mathrm{ab}$ & $0.31 \mathrm{ab}$ & $0.41 \mathrm{~b}$ & $28.0 \mathrm{~b}$ \\
M061122-10 & $1.15 \mathrm{~b}$ & $0.30 \mathrm{ab}$ & $0.58 \mathrm{ab}$ & $31.1 \mathrm{ab}$ \\
M061122-12 & $1.41 \mathrm{a}$ & $0.35 \mathrm{a}$ & $0.53 \mathrm{ab}$ & $36.7 \mathrm{a}$ \\
CK & $1.22 \mathrm{ab}$ & $0.27 \mathrm{ab}$ & $0.46 \mathrm{~b}$ & $30.6 \mathrm{ab}$ \\
\end{tabular}

Bacterial isolates M060706-5, M060824-7, M060824-8, M061122-2, M061122-5b, M061122-10 and M061122-12 were mostly related to Ensifer adhaerens, Curtobacterium luteum, Mycobacterium mucogenicum, Paenibacillus glycanilyticus, Cupriavidus pauculus, Bacillus bataviensis and Brevibacillus agri, respectively. Each value is the average of five replications

$C K$ control without inoculation

Data with different letters in the same columns are significantly different by DMRT tests at $P<0.05$

\section{Improvement of AMF colonization and plant growth by SAB}

Seven bacterial isolates were selected to co-inoculate alfalfa with G. margarita. It was shown that three isolates (strains M060706-5, M060824-7, or M061122-10) significantly improved the fungal colonization and/or the plant growth (Table 2). The fresh weight of alfalfa roots treated with isolate M060706-5 (the mostly related to Ensifer adhaerens) was 1.58 times of the control group. The fresh or dry weights of plant shoot treated with isolate M060824-7 (the mostly related to Curtobacterium luteum) had 0.37 or 0.36 time increment compared to non-inoculated group. At the same time, inoculation with isolates M060706-5 or M061122-10 (the mostly related to Bacillus bataviensis) led to the increment of fungal colonization by 47 or $48 \%$, respectively (Table 2). Previous studies also showed that bacteria associated with AMF enhanced the mycorrhization and plant growth, and the helper bacteria of AMF could be used as microbial inoculations for plant growth promotion (Xavier and Germida 2003; Bidondo et al. 2016). Further understanding the interactions between the AMF and these helper bacteria would help to reveal the promoting mechanism.

Acknowledgements This work was supported by the Research Fund for the Advanced Talents, Nanjing Forestry University (GXL201311).

\section{Compliance with ethical standards}

Conflict of interest The authors declare that they have no conflict of interest.

Open Access This article is distributed under the terms of the Creative Commons Attribution 4.0 International License (http:// creativecommons.org/licenses/by/4.0/), which permits unrestricted use, distribution, and reproduction in any medium, provided you give appropriate credit to the original author(s) and the source, provide a link to the Creative Commons license, and indicate if changes were made.

\section{References}

Ames RN, Mihara KL, Bayne HG (1989) Chitin-decomposing actinomycetes associated with a vesicular-arbuscular mycorrhizal fungus from a calcareous soil. New Phytol 111:67-71. doi:10.1111/j.1469-8137.1989.tb04219.x

Araújo WL, de Angellis DA, Azevedo JL (2004) Direct RAPD evaluation of bacteria without conventional DNA extraction. Braz Arch Biol Technol 47:375-380. doi:10.1590/S151689132004000300006

Bécard G, Douds DD, Pfeffer PE (1992) Extensive in vitro hyphal growth of vesicular-arbuscular mycorrhizal fungi in the presence of $\mathrm{CO}_{2}$ and flavonols. Appl Environ Microbiol 58:821-825

Bidondo LF, Colombo R, Bompadre J, Benavides M, Scorza V, Silvani V, Pérgola M, Godeas A (2016) Cultivable bacteria associated with infective propagules of arbuscular mycorrhizal fungi. Implications for mycorrhizal activity. Appl Soil Ecol 105:86-90. doi:10.1016/j.apsoil.2016.04.013

Brosius J, Dull TJ, Sleeter DD, Noller HF (1981) Gene organization and primary structure of a ribosomal DNA operon from Escherichia coli. J Mol Biol 148:107-127. doi:10.1016/00222836(81)90508-8

Cocolin L, Manzano M, Cantoni C, Comi G (2001) Denaturing gradient gel electrophoresis analysis of the 16S rRNA gene V1 region to monitor dynamic changes in the bacterial population during fermentation of Italian sausages. Appl Environ Microbiol 67:5113-5121. doi:10.1128/AEM.67.11.5113-5121.2001

Cruz AF, Horii S, Ochiai S, Yasuda A, Ishii T (2008) Isolation and analysis of bacteria associated with spores of Gigaspora margarita. J Appl Microbiol 104:1711-1717. doi:10.1111/j. 1365-2672.2007.03695.x

El-Sayed WS, Akhkha A, El-Naggar MY, Elbadry M (2014) In vitro antagonistic activity, plant growth promoting traits and phylogenetic affiliation of rhizobacteria associated with wild plants grown in arid soil. Front Microbiol 5:651. doi:10.3389/fmicb. 2014.00651

Garbaye J (1994) Helper bacteria: a new dimension to the mycorrhizal symbiosis. New Phytol 128:197-210. doi:10.1111/j.14698137.1994.tb04003.x

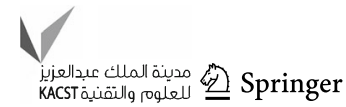


Hildebrandt U, Janetta K, Bothe H (2002) Towards growth of arbuscular mycorrhizal fungi independent of a plant host. Appl Environ Microbiol 68:1919-1924. doi:10.1128/AEM.68.4.19191924.2002

Karandashov V, Kuzovkina I, Hawkins HJ, George E (2000) Growth and sporulation of the arbuscular mycorrhizal fungus Glomus caledonium in dual culture with transformed carrot roots. Mycorrhiza 10:23-28. doi:10.1007/s005720050283

Lecomte J, St-Arnaud M, Hijri M (2011) Isolation and identification of soil bacteria growing at the expense of arbuscular mycorrhizal fungi. FEMS Microbiol Lett 317:43-51. doi:10.1111/j.15746968.2011.02209.x

Levy A, Merritt AJ, Mayo MJ, Chang BJ, Abbott LK, Inglis TJJ (2009) Association between Burkholderia species and arbuscular mycorrhizal fungus spores in soil. Soil Biol Biochem 41:1757-1759. doi:10.1016/j.soilbio.2009.05.004

Long L, Zhu H, Yao Q, Ai Y (2008) Analysis of bacterial communities associated with spores of Gigaspora margarita and Gigaspora rosea. Plant Soil 310:1-9. doi:10.1007/s11104008-9611-7

Mcgonigle TP, Miller MH, Evans DG, Fairchild GL, Swan JA (1990) A new method which gives an objective measure of colonization of roots by vesicular-arbuscular mycorrhizal fungi. New Phytol 115:495-501. doi:10.1111/j.1469-8137.1990.tb00476.x

Rivera ING, Lipp EK, Gil A, Choopun N, Huq A, Colwell RR (2003) Method of DNA extraction and application of multiplex polymerase chain reaction to detect toxigenic Vibrio cholerae
O1 and O139 from aquatic ecosystems. Environ Microbiol 5:599-606. doi:10.1046/j.1462-2920.2003.00443.x

Salvioli A, Chiapello M, Fontaine J, Hadj-Sahraoui AL, Grandmougin-Ferjani A, Lanfranco L, Bonfante P (2010) Endobacteria affect the metabolic profile of their host Gigaspora margarita, an arbuscular mycorrhizal fungus. Environ Microbiol 12:20832095. doi:10.1111/j.1462-2920.2010.02246.x

Scheublin TR, Sanders IR, Keel C, van der Meer JR (2010) Characterisation of microbial communities colonising the hyphal surfaces of arbuscular mycorrhizal fungi. ISME J 4:752-763. doi:10.1038/ismej.2010.5

Selvakumar G, Krishnamoorthy R, Kim K, Sa TM (2016) Genetic diversity and association characters of bacteria isolated from arbuscular mycorrhizal fungal spore walls. PLoS One 11(8):e0160356. doi:10.1371/journal.pone.0160356

Sundram S, Meon S, Seman IA, Othman R (2011) Symbiotic interaction of endophytic bacteria with arbuscular mycorrhizal fungi and its antagonistic effect on Ganoderma boninense. J Microbiol 49(4):551-557. doi:10.1007/s12275-011-0489-3

Taktek S, Trépanier M, Servin PM, St-Arnaud M, Piché Y, Fortin J-A, Antoun H (2015) Trapping of phosphate solubilizing bacteria on hyphae of the arbuscular mycorrhizal fungus Rhizophagus irregularis DAOM 197198. Soil Biol Biochem 90:1-9. doi:10.1016/j.soilbio.2015.07.016

Xavier LJC, Germida JJ (2003) Bacteria associated with Glomus clarum spores influence mycorrhizal activity. Soil Biol Biochem 35:471-478. doi:10.1016/S0038-0717(03)00003-8 